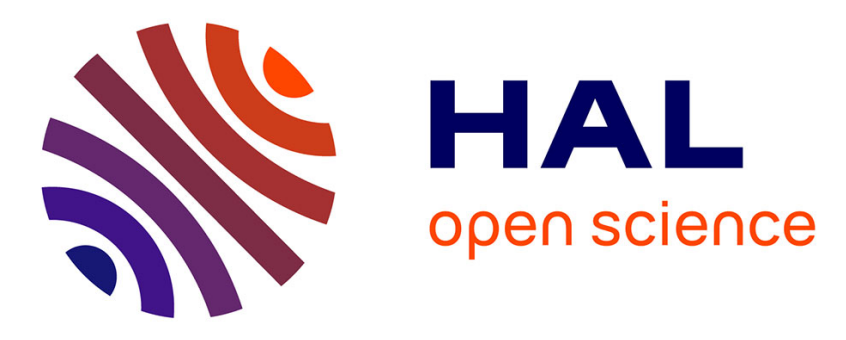

\title{
Candidate biomarker discovery in plasma of juvenile cod () exposed to crude North Sea oil, alkyl phenols and polycyclic aromatic hydrocarbons (PAHs)
}

Anneli Bohne-Kjersem, Arnfinn Skadsheim, Anders Goksøyr, Bjørn Einar

Grøsvik

\section{To cite this version:}

Anneli Bohne-Kjersem, Arnfinn Skadsheim, Anders Goksøyr, Bjørn Einar Grøsvik. Candidate biomarker discovery in plasma of juvenile cod () exposed to crude North Sea oil, alkyl phenols and polycyclic aromatic hydrocarbons (PAHs). Marine Environmental Research, 2009, 68 (5), pp.268. 10.1016/j.marenvres.2009.06.016 . hal-00563091

\section{HAL Id: hal-00563091 \\ https://hal.science/hal-00563091}

Submitted on 4 Feb 2011

HAL is a multi-disciplinary open access archive for the deposit and dissemination of scientific research documents, whether they are published or not. The documents may come from teaching and research institutions in France or abroad, or from public or private research centers.
L'archive ouverte pluridisciplinaire HAL, est destinée au dépôt et à la diffusion de documents scientifiques de niveau recherche, publiés ou non, émanant des établissements d'enseignement et de recherche français ou étrangers, des laboratoires publics ou privés. 


\section{Accepted Manuscript}

Candidate biomarker discovery in plasma of juvenile cod (Gadus morhua) exposed to crude North Sea oil, alkyl phenols and polycyclic aromatic hydrocarbons (PAHs)

Anneli Bohne-Kjersem, Arnfinn Skadsheim, Anders Goksøyr, Bjørn Einar Grøsvik

PII: S0141-1136(09)00086-5

DOI: 10.1016/j.marenvres.2009.06.016

Reference: MERE 3355

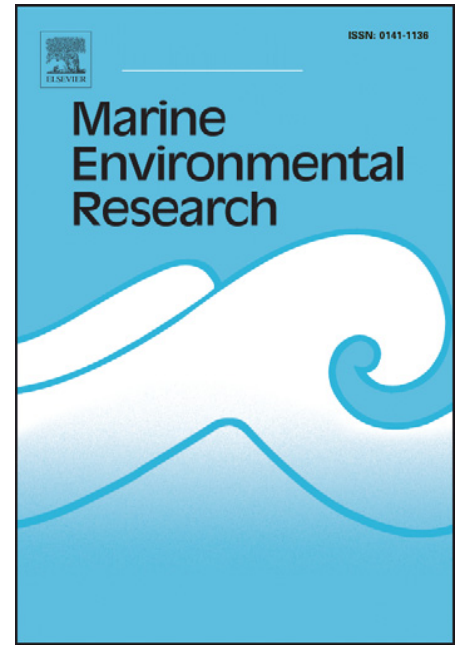

To appear in:

\section{Marine Environmental Research}

Received Date: $\quad 13$ February 2009

Revised Date: $\quad 19$ June 2009

Accepted Date: $\quad 24$ June 2009

Please cite this article as: Bohne-Kjersem, A., Skadsheim, A., Goksøyr, A., Grøsvik, r.E., Candidate biomarker discovery in plasma of juvenile cod (Gadus morhua) exposed to crude North Sea oil, alkyl phenols and polycyclic aromatic hydrocarbons (PAHs), Marine Environmental Research (2009), doi: 10.1016/j.marenvres.2009.06.016

This is a PDF file of an unedited manuscript that has been accepted for publication. As a service to our customers we are providing this early version of the manuscript. The manuscript will undergo copyediting, typesetting, and review of the resulting proof before it is published in its final form. Please note that during the production process errors may be discovered which could affect the content, and all legal disclaimers that apply to the journal pertain. 
1 Candidate biomarker discovery in plasma of juvenile

2 cod (Gadus morhua) exposed to crude North Sea oil,

3 alkyl phenols and polycyclic aromatic hydrocarbons

4 (PAHs)

5

6 Anneli Bohne-Kjersem ${ }^{1, \xi}$, Arnfinn Skadsheim ${ }^{2}$, Anders Goksøyr ${ }^{1,3}$, and Bjørn Einar

$7 \quad$ Grøsvik $^{1,4}$

8

$9{ }^{1}$ Department of Molecular Biology, University of Bergen, PB 7800, N-5020 Bergen,

10 Norway

$11{ }^{2}$ International Research Institute of Stavanger AS, Mekjarvik 12, N-4070 Randaberg,

12 Norway

$13{ }^{3}$ Biosense Laboratories AS, Thormøhlensgt. 55, N-5020 Bergen, Norway

$14{ }^{4}$ Institute of Marine Research, PO Box 1870, N-5817 Nordnes, Bergen, Norway

$15 \xi^{\xi}$ Present address: Det Norske Veritas, Johan Berentsensvei 109-111, N-5020 Bergen,

16 Norway

17

18 Corresponding author: Anneli Bohne-Kjersem

19

20 Email: anneli@.bohnekjersem.net

21 Phone: +4755 $584500 /+4790094457$

22 Fax: +4755 589683

23

24 Keywords: Atlantic cod, biomarkers, crude oil, plasma, produced water, proteomics 


\section{Abstract}

2

3 In this study we have investigated protein changes in plasma of juvenile Atlantic cod

4 (Gadus morhua) induced by crude North Sea oil and North Sea oil spiked with alkyl

5 phenols and polycyclic aromatic hydrocarbons, a surrogate produced water

6 composition. Using a proteomic approach, we identified 137 differentially expressed

7 proteins at different levels of crude oil exposure. Many of the induced protein changes

8 occurred at low levels of exposure. The results obtained with protein expression

9 profiles after exposure to oil and surrogate produced water indicate effects on

10 fibrinolysis and the complement cascade, the immune system, fertility-linked proteins,

11 bone resorption, fatty acid metabolism as well as increased oxidative stress, impaired

12 cell mobility and increased levels of proteins associated with apoptosis. Although the

13 number of individuals and samples in this study is limited within each treatment

14 group, the protein changes observed in this study represent a first screening for

15 potential biomarker candidates in cod plasma reflecting potential effects of crude oil

16 and produced water exposure on fish. 


\section{Introduction}

2

3 The three main sources of continuous oil discharges offshore are produced water,

4 displacement water and drainage water (OLF, 2005). Of these, produced water is by

5 far the most dominant, containing a great variety of compounds, including dissolved

6 inorganic salts, minerals and heavy metals, dissolved and dispersed oil compounds, as

7 well as organic compounds such as carboxylic acids and phenols from the formation

8 water (Neff, 2002). The maximum permitted concentration of oil in discharged

9 produced water is $30 \mathrm{mgL}^{-1}$ (30ppm) (OSPAR, 2006). The most well studied

10 compounds of produced water, polycyclic aromatic hydrocarbons (PAHs) and alkyl

11 phenols, have been reported to cause severe effects on marine wildlife (Nicholas,

12 1999; Aas et al., 2000; Evanson \& van der Kraak, 2001; Schwaiger et al., 2002;

13 Cardinali et al., 2004; Meier et al., 2007).

14

15 In addition to the release of compounds through routine discharges of produced water,

16 the accidents and threats of blow-outs or oil tankers spilling large amounts of oil

17 offshore are incidents of great concern. Previously, negative effects from oil spills

18 have been reported (Solé et al., 1996, Carls et al., 2001, Jewett et al., 2002, Lee and

19 Anderson, 2005).

20

21 The development of oil fields may represent a conflict with fisheries interests. In the

22 North Sea, many of the oil and gas installations are situated in areas inhabited by large

23 fish populations. According to a recent risk assessment, the risk area in the vicinity of

24 oil platforms could contain up to twice the average fish density as the whole North

25 Sea area (Myhre et al., 2005). Oil discharges and spills in these areas may therefore 
1 have the potential to affect a large number of individual fish for prolonged periods,

2 possibly also at more sensitive life stages, for example during early development.

3 Adequate biomonitoring tools, such as sensitive biomarkers, that can detect and

4 monitor the effect of low chronic exposure as well as larger acute exposures are

5 therefore of great importance to regulatory authorities, as a basis for better

6 environmental risk assessment.

7

8 Here, we have studied the effects of crude North Sea oil singly or spiked with PAHs

9 and alkyl phenols on cod using a proteomic approach. By using two-dimensional

10 electrophoresis (2DE) and image analysis we identified protein changes in cod

11 plasma, that were considered as promising biomarker candidates for the biological

12 effects of oil and produced water to fish. The proteins were isolated from 2DE-gels

13 and identified by mass spectrometry (MS), searching a new cod genome database

14 based on expressed sequence tags (ESTs). 


\section{Materials and methods}

2

\section{Materials}

4

5

\section{Norway).}

13 Bovine Serum Albumin, BSA, 3-(3-colamidopropyl)-dimetylammonio-114 propansulfoanat, CHAPS, Triton X-100, DL-dithiothreitol, DDT, iodoacetamide, 15 alpha-cyano-4-hydroxycinnamic acid, CHCA and 4-sulfophenyl isothiocyanate, 16 sodium salt monohydrate, SPITC, were purchased from Sigma Aldrich (by, MO, US). 17 Ampholine ${ }^{\mathrm{TM}}$ 3,5-10, DryStrip Cover fluid, and IEF Electrode strips were purchased 18 from GE Healthcare (Uppsala, Sweden).

19

20 Ammonium dodecyl sulfate, SDS, Agarose, 30\% Acrylamide/Bis solution, 37.5:1, 21 Ammonium persulfate, temed and Precision Plus Protein ${ }^{\mathrm{TM}}$ standard were purchased 22 from Bio-Rad (Hercules, CA, US). Trypsin was purchased from Promega (Madison, 23 WI, US), while Poros 20R2, Reverse Phase packing, was purchased from Applied 24 Biosystems (Foster City, CA, US). GelLoader tips were provided by Eppendorf 25 (Hamburg, Germany), and siliconised tubes were provided by Sorenson BioScience, 
1 Inc (Salt Lake City, UT, US). Peptide Calibration Standard and MTP384 Target plate

2 polished steel TF were purchased from Bruker Daltonics (Leipzig, Germany).

3

\section{Experimental design}

5

6 Fish

7 Juvenile cod (0-group) were purchased from an aquaculture facility, Sagafjord in

8 Leirvik at Stord, Norway (North Sea Norwegian coastal origin), four weeks prior to

9 the start of the exposure (October, 2002). The fish were maintained in 530 litre tanks

10 and fed commercial cod pellets (Skretting). Feeding was stopped two to three days

11 before sampling in order to encourage accumulation of bile in the gall bladder. The

12 sea water was taken from the $78 \mathrm{~m}$ depth water intake at Akvamiljø (Mekjarvik,

13 Stavanger, Norway). The water salinity and temperature ranged from 33-34 ppt and

$14 \quad 8-12{ }^{\circ} \mathrm{C}$ during the acclimation period. During the exposure period the temperature

15 ranged from $10-11.5^{\circ} \mathrm{C}$, whilst the salinity was as for the storage period. The fish

16 were carefully transferred to avoid skin lesions and to minimize behavioural stress to

17 the five experimental tanks one week prior to the start of the oil exposure. Five fish

18 were sampled each time from each tank. The fish were sacrificed with a blow to the

19 head and dissected for sampling of blood and liver tissue. In order to minimize stress

20 during the experiment, length and weight were only measured at the sampling time.

21 The mean total wet weight of the fish was $40.5 \pm 12.3 \mathrm{~g}$ and the mean length was 16.7

$22 \pm 1.5 \mathrm{~cm}$. Blood samples were taken by a heparin-coated syringe which was inserted

23 between the first and second caudal fin and towards the chorda until the main blood

24 vessel was hit. The blood sample was centrifuged at $2000 \mathrm{~g}$ for 5 minutes at $4{ }^{\circ} \mathrm{C}$.

25 Thereafter the plasma was removed by a pipette to cryo-vials and frozen at $-78{ }^{\circ} \mathrm{C}$. 


\section{Exposure}

3 The cod were exposed for 24 days, and sampled at day 3, 14 and 24. Five exposures

4 were set up including control. The cod were exposed to three levels of crude oil: 0.06

$5 \quad \mathrm{mg}$ oil $\mathrm{kg}^{-1}$ seawater $\left(=\mathrm{mgL}^{-1}=\mathrm{ppm}\right)$ - low levels, $0.25 \mathrm{mgL}^{-1}-$ medium levels, and

$61.0 \mathrm{mgL}^{-1}$ - high levels of crude oil, as well as one group exposed to $1.0 \mathrm{mgL}^{-1}$ crude

7 oil spiked with polyaromatic hydrocarbons and alkyl phenols (for details see below).

8 Only samples from day 3 and day 24 were used in the present study.

9

$10 \quad$ Oil

11 The oil dispersions were made in the continuous flow system (CFS), using Statfjord B

12 field crude oil. The oil was in each experiment dispersed in seawater as droplets with

13 mean and median diameters in the $11-13 \mu \mathrm{m}$ range. Initially the oil was dispersed at 5

$14 \mathrm{mg}$ oil $/ \mathrm{kg}$ seawater $\left(\mathrm{mgL}^{-1}\right)$, and the dispersion was distributed via a manifold with

15 overflow to a second set of manifolds with overflows. These secondary manifolds

16 received the $5 \mathrm{mgL}^{-1}$ oil dispersion at various rates through peristaltic pumps.

17 Seawater diluting the oil dispersion was added by gravity and controlled by valves

18 from a header tank with overflow. The overflow ensured stable pressure in the water

19 supplies in the system. Four different solutions involving dispersed crude oil were

20 made in addition to seawater. The levels of hydrocarbons in water and of hydrocarbon

21 uptake in fish following the exposure, are reported in Skadsheim (2005).

\section{Surrogate produced water}


1 The spike was initially made as a concentrated stock solution comprised of the

2 hydrocarbons dissolved in acetone. The spike hydrocarbon mixture in acetone was

3 first pumped into a mixing flask that also received seawater. This first step of dilution

4 generated a concentration of $0.8 \mathrm{mgL}^{-1}$ seawater per sum alkyl phenols or PAHs. This

5 solution was then fed by gravity and valve control to a second mixing flask and a

6 manifold, which provided a final concentration at $0.2 \mathrm{mgL}^{-1}$ hydrocarbon solution of

7 each of the two spike substance groups. This flask also received an oil emulsion fed

8 via a peristaltic pump to provide the final $1 \mathrm{mgL}^{-1}$ oil in seawater emulsion plus the

9 diluted spike composition. The final amount of the acetone carrier in the spike

10 exposure solution was $20 \mu \mathrm{g}$ acetone $\mathrm{L}^{-1}$ water. Hydrocarbon levels in water and the

11 level of hydrocarbon uptake in fish following the exposure are reported in Skadsheim

12 (2005).

13

14 


\section{Methods}

2

3 2DE

4

5 The protein concentration of the plasma samples was determined according to

6 Bradford (1976). For analytical gels, $20 \mu \mathrm{g}$ of sample was diluted in re-hydration

7 buffer (7M urea, 2M thiourea, 4\% CHAPS, $20 \mathrm{mM} \mathrm{DTT,} \mathrm{0.5 \%} \mathrm{v/v} \mathrm{Triton} \mathrm{X-100,}$

$8 \quad 0.5 \% \mathrm{v} / \mathrm{v}$ Ampholine 3-10, bromphenol blue) and applied to IPG strips $\mathrm{pH} \mathrm{4-7,7} \mathrm{cm}$

9 (GE Healthcare) (O’Farrell, 1975, Görg et al., 1988 \& 2000). For preparative gels,

$101000 \mu \mathrm{g}$ of sample was diluted in re-hydration buffer and added to IPG strips $\mathrm{pH} 4-7$,

$1118 \mathrm{~cm}$. The strips were then re-hydrated for a minimum of 12 hours and focused on a

12 Multiphor II unit (GE Healthcare) according to the manufacturer's guidelines. The

13 strips were equilibrated for $15 \mathrm{~min}$. at room temperature in $0.25 \%$ DTT-containing

14 SDS equilibration buffer (50 mM Tris $\mathrm{pH} 8.8,6 \mathrm{M}$ urea, 30\% (v/v) glycerol, $2 \%$

15 (w/v) SDS, bromphenol blue) and $15 \mathrm{~min}$. in a $4.5 \%$ iodoacetamide-containing SDS

16 equilibration buffer (O’Farrell, 1975, Görg et al., 1988 \& 2000) prior to separation in

17 the second dimension on 9\% SDS-PAGE gels (Laemmli, 1970). Analytical gels were

18 run at $200 \mathrm{~V}, 400 \mathrm{~mA}$ per 12 gels, $20^{\circ} \mathrm{C}$ for $45 \mathrm{~min}$. in a mini-Dodeca unit (Bio-Rad)

19 prior to silver-staining (Heukeshoven \& Dernick, 1988). Preparative gels were run in

20 an Ettan Dalt Six/Twelve unit at $1 \mathrm{~W}$ per gel, $20^{\circ} \mathrm{C}$, for approximately $17 \mathrm{~h}$. The

21 preparative gels were then stained with Collodial Coomassie (Neuhoff et al, 1988). 


\section{Gel image analysis}

2

3 Silver-stained analytical gels and Coomassie-stained preparative gels were scanned on

4 a GS-800 Calibrated Densitometer flatbed scanner (Biorad, CA, US) using PDQuest

5 7.2.0 software (Biorad, CA, US). The gels were scanned with medium resolution:

$6 \quad 63.5(\mathrm{X}) \times 63.5(\mathrm{Y})$ microns.

7

8 The scanned 2DE images were sent to Ludesi Analysis Centre (Sweden) for

9 professional image analysis. At Ludesi Analysis Centre the spots were automatically

10 detected and the results were manually verified and edited where needed. The gels

11 were automatically matched using all-to-all matching, every gel was matched to all

12 other gels, avoiding introduction of bias caused by use of a reference gel. The

13 matching was iteratively improved by optimization of matching parameters and

14 manual editing where needed. Integrated intensities were measured for each spot,

15 background corrected, and then normalized. Normalization removes systematic gel

16 differences originating from variations in staining, scanning time, protein loading, etc,

17 by mathematically minimizing the median expression difference between matched

18 spots.

19

20 One-way ANOVA-analysis ( $\mathrm{p} \leq 0.05$ and fold change $\geq 2$ ) was performed comparing 21 the level of protein expression to level of exposure using Ludesi 2DE Interpreter 22 (www.ludesi.com). 


\section{Mass spectrometry}

2

3 The excised protein spots were in-gel digested according to the method of

4 Shevchenko et al. (1996) prior to mass spectrometry. The excised gel plugs were

5 washed in digestion buffer $\left(50 \mathrm{mM} \mathrm{NH}_{4} \mathrm{HCO}_{3}, \mathrm{pH} 7.8\right)$ /acetonitrile (60/40) and dried

6 by vacuum centrifugation. Modified trypsin $\left(10 \mathrm{ng}^{-1} \mathrm{l}^{-1}\right)$ dissolved in $50 \mathrm{mM}$

$7 \mathrm{NH}_{4} \mathrm{HCO}_{3}, \mathrm{pH} 7.8$, was added to the dry gel pieces and incubated on ice for $1 \mathrm{~h}$. After

8 removing the supernatant, additional digestion buffer was added and the digestion was

9 continued at $37^{\circ} \mathrm{C}$ over night.

10

\section{De novo-sequencing}

12 4-sulphophenyl isothiocyanate, SPITC, was used to sulfonate trypsin-digested 13 peptides to yield good y-ion sequences at low peptide concentrations for improved 14 protein identification (Marekov and Steinert, 2003). SPITC diluted in $20 \mathrm{mM}$ $15 \mathrm{NaHCO}$, $\mathrm{pH} 8.6$ to a concentration of $10 \mu g \mu \mathrm{l}^{-1}$ was added to the peptide solution 16 and incubated at $30 \mathrm{~min}$. at $50^{\circ} \mathrm{C}$. The reaction was terminated by adding $1 \mu 15 \%$ 17 TFA. The SPITC-derivated proteins were then applied to nano-columns packed with 18 20Poros R2 (Gobom et al., 1999). The Column was washed with 0.1\% TFA and 19 eluted with matrix, $\alpha$-cyano-4-hydroxycinnamic acid (CHCA) in 70\% ACN/0.1\% 20 TFA on to the steel target prior to MALDI-ToF-ToF (4700 Proteomics Analyser, 21 Applied Biosystem, Foster City, CA, US). Signal-to-noise ratio was set to 20, mass 22 tolerance was set to $\pm 0.5 \mathrm{~m} / \mathrm{z}$ and mass outlet factor was set to 10 .

24 MALDI-ToF-ToF spectra of trypsin-digested peptides and SPITC-treated trypsin25 digested peptides were compared, and fragments that by this comparison were found 
1 to be sulfonated were manually selected for further fragmentation and de novo-

2 sequencing.

3

\section{LC-ESI-Q-ToF}

5 Prior to application of sample on the LC-ESI-Q-ToF, $20 \mu \mathrm{L}$ trypsin-digested protein

6 samples of isolated 2DE-spots were run on home-made $\mathrm{C}_{18}$ Stage tip columns

7 (Rappsilber et al., 2003), and the samples were eluted with 1/10 of sample volume of

$8 \quad 100 \%$ acetonitril (ACN) and dissolved in approximately $2 \mathrm{x}$ sample volume of $2 \%$

9 formic acid (FA). $40 \mu \mathrm{L}$ of the dissolved sample was applied on the ESI-LC-QToF

10 instrument.

11

12 The samples were applied to an Ultimate 3000 nano-LC (Dionex Corporation, USA).

13 The nano-LC consist of a $\mathrm{C}_{18}$ Pepmap 100 pre-column (Dionex Corporation, USA)

14 with bead size $5 \mu \mathrm{m}$, pore size $100 \AA$, and a $\mathrm{nC}_{18}$ analytical column, $\mathrm{C}_{18}$ Pepmap 100

15 (Dionex Corporation, USA), with bead size $3 \mu \mathrm{m}$ and pore size $100 \AA$ in the first set-

16 up, and with bead size $5 \mu \mathrm{m}$ and pore size $100 \AA$ in the second set-up. The flow rate on

17 the analytical column was $300 \mathrm{nLmin}^{-1}$, mobile phase A was $2 \% \mathrm{ACN}$ and $0.1 \% \mathrm{FA}$,

18 and mobile phase $\mathrm{B}$ was $90 \% \mathrm{ACN}$ and $0.1 \% \mathrm{FA}$. The following gradient was used:

19 0-3 min; 5\% B; 3-40 min.: 5-50\% B; 40-45 min.: 50-95\% B; $45-53$ min.: 95\% B; $53-$

$2055 \min .: 95-5 \%$ B; $55-70$ min.: $5 \%$ B.

21

23 The collision energy followed a step-wise increment profile according to ion mass and 24 charge, the collision energy increasing to $53 \mathrm{kV}$ for $2+$ ions and to $42 \mathrm{kV}$ for $3+$ ions.

25 Data were acquired sequentially in MS-mode, with scan range (m/z) 450-1100 Da. 
1 MS/MS spectra of 3 ions from the MS-scan were recorded, within the mass range of

2 50-1500 Da. Only parent ions with two or three charges were chosen for MS/MS and

3 the selection width of precursor ion was $2 \mathrm{Da}$.

4 The resulting MS/MS data were managed by Mass Lynx 4.0 software (Micromass)

5 and MS_Lims (http://genesis.ugent.be/ms_lims/).

\section{Database searches}

9 The cod EST database used for protein identification included more than 50,000 EST

10 sequences from cod from a project at the Institute of Marine Research, Norway,

11 NIFES (Norwegian Institute of Research on Nutrition and Seafood) and groups

12 affiliated to the National Research Council, Canada. The annotation of the sequences

13 was performed by the Computational Biology Unit at Unifob (Bergen, Norway),

14 producing approximately 6000 contigs and more than 30,000 singlets. The EST

15 sequences are derived from cDNA libraries of cod exposed to an array of

16 environmental pollutants, such as PCBs and heavy metals, and purified mRNA

17 sequences from several different tissues. RNA was also purified from cod captured in

18 the marinas of Bergen and Trondheim, and therefore assumed to be exposed to a

19 battery of pollutants, as well as cod exposed to hypoxia and hyperoxia

20 (http://www.codstress.olsvik.info/Results.html).

22 The obtained de-novo sequence data from SPITC-MALDI-ToF-ToF were initially

23 used in BLAST-searches in the in-house developed cod EST-database, and the 24 sequence of the contig(s) and/or singlets which matched the query sequences 25 (minimum two fragments with score >identity threshold score and E-values $>0.05$ ) 
1 were retrieved and used in a second blast-search in the NCBInr database

2 (http://www.ncbi.nlm.nih.gov/BLAST/Blast.cgi) for protein identity (Altschul et al., 3 1997).

4 The sequence data from the LC-MS-MS runs were used in MASCOT-searches in the 5 cod EST-database (Perkins et al., 1999, Steen \& Mann, 2004) using the following 6 parameters: Missed cleavages: 1 ; Significance treshold $\mathrm{p}<0.05$; $\mathrm{MS}^{1}$ mass accuracy:

$7 \quad 0.5 \mathrm{Da}, \mathrm{MS}^{2}$ mass accuracy: $0.3 \mathrm{Da}$; Partial modifications: Carbamidomethyl (C) and

8 Oxidation (M). The quality of the matches was manually inspected. The sequence of 9 the contig(s) and/or singlets which matched the query sequences (minimum two 10 fragments with score>identity threshold score and E-values $>0.05$ ) were retrieved and 11 used in blast-search in the NCBInr database for protein identity. 


\section{Results}

\section{2DE and Image Analysis}

4

520 individual plasma samples were screened on 2DE and analysed for differentially 6 expressed proteins utilising the Ludesi 2DE Image Analysis Service. The dataset 7 comprise 9 male individuals and one female individual sampled after 3 days of 8 exposure, and 10 male individuals sampled after 24 days of exposure. The limited 9 number of samples within each group $(n=1-3)$ is due to varying distribution of males and females among the five individuals sampled within each treatment group.

11 Although sex was not documented to influence protein patterns here, we tried to use 12 only male fish for the present study. On average, approximately 840 proteins were 13 detected on the 2DE-gels. Screening analysis gave $78 \%$ average correctness, at both 14 day 3 and day 24 of exposure. The estimated total number of correctly identified 15 significant changes $(\mathrm{p}<0.05)$ were 465 .

16

17 Biomarker candidates were identified by comparing the global protein expression of 18 silver-stained mini-gels of individuals from 10 different treatment-groups, the 19 majority of groups consisting of two to three individuals. Protein changes only 20 observed in groups consisting only of one gel/individual sample were excluded. 137 21 protein changes with a fold change $\geq 2$ and $\mathrm{p}<0.05$ using one-way ANOVA were 22 identified as protein changes by crude oil and surrogate produced water exposure 23 (Table 1 and 2). Their localisation on a 2DE-gel is shown in Figure 1. Interestingly, 24 more than 40 of 137 protein changes occur at the lowest level of oil exposure $(\leq 0.06$ $25 \mathrm{mgL}^{-1}$ crude oil) (Table 1 and 2). 


\section{MS-MS}

3

4 Of the 137 protein spots on the silver-stained mini-gels evaluated to be differentially 5 expressed upon exposure, 29 proteins were positively identified by MS/MS (Table 3).

After 3 days of exposure (Table 1), fibrinogen (\#7013, \#7709) was increased in protein level by surrogate produced water exposure. Another protein identified as an alpha-2-antiplasmin (\#7550) was down-regulated after 3 days of crude oil exposure.

11 After 24 days of exposure (Table 2), enolase alpha (\#7011) was down-regulated by 12 crude oil and surrogate produced water exposure. Fibrinogen (\#7032) was up13 regulated at higher levels of crude oil and surrogate produced water exposure. Alpha14 2-antiplasmins, A2A, (\#7581, \#7584, \#7587, \# 7597) appeared to be up-regulated by 1524 days of $1.0 \mathrm{mgL}^{-1}$ crude oil and surrogate produced water exposure. Tropomyosin 16 (\#7043), serotransferrin (\#7192), hemopexin (\#7409), prothrombin (\#7285, \#7329) 17 and fetuin B (\#7098, \#7285,\#7345) was down-regulated by crude oil exposure and in 18 the cases of serotransferrin and pro-thrombin also by surrogate produced water 19 exposure. The latter exposure was also found to induce a down-regulation of 20 pentraxin (\#7027). Alpha-1-antitrypsin, A1AT (\#7811), was up-regulated by 0.25 $21 \mathrm{mgL}^{-1}$ of crude oil. The prepro-apolipoprotein A (\#8580) was shown to be up22 regulated at crude oil levels $\geq 25 \mathrm{mgL}^{-1}$ and by surrogate produced water exposure, 23 while NTPase (\#7810) was found to be down-regulated by $1.0 \mathrm{mgL}^{-1}$ crude oil and oil 24 spiked with PAHs and alkyl phenols. A protein similar to pregnancy zone protein, Pzp 25 (\#7826), was found to be down-regulated by crude oil exposures $\geq 1.0 \mathrm{mgL}^{-1}$. 
1 Apolipoprotein B (\#7178) was shown to be up-regulated by $0.25 \mathrm{mgL}^{-1}$ crude oil

2 exposure and by surrogate produced water exposure.

3

4 Discussion

5 This proteomics-based study of protein expression profiles after exposure of juvenile

6 Atlantic cod to oil and surrogate produced water indicate effects on fibrinolysis and

7 the complement cascade, the immune system, fertility-linked proteins, bone

8 resorption, fatty acid metabolism as well as increased oxidative stress, impaired cell

9 mobility and increased levels of proteins associated with apopotosis.

10

11 Chemical analysis of the water samples by fluorescence demonstrate that mean values

12 of $45-72 \%$ of the nominal doses of total hydrocarbons could be recorded over the

13 exposure period, whereas GC/MS analysis detected $80-100 \%$ of total PAH

14 (Skadsheim, 2005). Bile PAH metabolites reflected a clear and significant correlation

15 between exposure levels and levels of metabolites in the bile when measured by fixed

16 fluorescence and by GC/MS (ibid.).

17

18 Although the number of individuals and samples in this study is limited within each

19 treatment group, all the ANOVA analyses included a minimum of ten gels, and

20 protein changes only apparent in groups of one individual were excluded from the

21 analysis. The protein changes observed in this study may therefore represent a first

22 screening for potential biomarker candidates in cod plasma that will be further

23 analysed and verified in future exposure studies based on a larger number and broader

24 range of samples. 


\section{Image analysis and changes in the protein pattern}

2

3 Using a 2D-gel based strategy in toxicoproteomics, there will always be a gel to-gel

4 variation and a technical variation in addition to the biological variation and changes

5 in the protein pattern caused by xenobiotic exposure (Molloy et al., 2003). The gel togel variation includes differences in gel size, in the protein amount loaded to the strips and absorbed by the strips, as well as staining efficiency. Good warping- and normalisation-functions prior to spot detection and matching, are therefore crucial to the final result. The Ludesi service provided in our view robust image analysis in which the spots of different spot patterns on different 2DE gels appeared to correspond well to the corresponding spots in the other gels. For these, an appropriate normalisation function was applied providing accurate spot detection and protein expression measurement. The average correctness of the Ludesi image analysis was calculated to be far better than the average correctness of that of PDQuest, another image analysis software used in our lab. Using PDQuest, we had trouble obtaining satisfactory warping (correspondence of 2D gel spot patterns, removal of gel distortions), and satisfactory matching (correspondence of individual spots between different 2DE gels) resulting in poor and inaccurate spot detection.

\section{Biomarker candidates}

After 3 days of exposure, fibrinogen was up-regulated after surrogate produced water exposure and there was a down-regulation of A2A following crude oil exposure. After 24 days of exposure, we observed a down-regulation of alpha enolase and prothrombin, and an up-regulation of alpha-2-antiplasmin and fibrinogen, proteins which are involved in the fibrinolytical system. These changes suggest an effect on 
1 the fibrinolytical system following crude oil exposure. Alpha-1-antitrypsin (A1AT)

2 was up-regulated.

3

4 The observed changes of expression of A1AT and alpha-enolase also indicate an

5 effect on the immune system. A1AT is known to be linked to immunological and

6 inflammatory disorders and is also found to be regulated by sex-hormones

7 (Machovich \& Horvath, 1981, Yamamoto \& Sinohara, 1984, Schwarzenberg et al.,

8 1987). Impairment of alpha-enolase activity is reported to be involved in a large

9 variety of infectious and autoimmune diseases, microbial tissue invasion, endothelial

10 injury, activation of the complement classical pathway, perturbations of the

11 fibrinolytical system, as well as induction of apoptotic cell death (Terrier et al., 2007).

12 Pentraxin may also indicate an effect on the immune system, as short pentraxins are

13 acute phase proteins, produced in liver in response to inflammation, as reviewed by

14 Bottazi et al., (2006).

15

16 We also identified a down-regulation of Pzp-(pregnancy zone protein)-resembling

17 protein after crude oil exposure $\left(\geq 0.25 \mathrm{mgL}^{-1}\right)$ and an up-regulation of A2A. Alpha-2-

18 antiplasmin constitutes a key recognition sequence for cell adhesions (Thomas et al.,

19 2007), and has been reported to enhance cell aggregation and suppress cell mobility

20 (Hayashido et al., 2007). It has also been found to be involved in mammalian

21 spermatogenesis, sperm capacitation, and fertilization, as reviewed by Liu (2007).

22 These changes may indicate an effect of oil hydrocarbons or other components of 23 crude oil on the fertility of fish. 
1 Tropomyosin forms complexes with several different proteins, including actin,

2 involved in cell adhesion to surfaces. The apparent change in tropomyosin expression

3 after crude oil exposure, together with the apparent change in A2M expression may

4 imply effects of crude oil exposure on cell adhesion.

6 Serotransferrin and hemopexin are important constituents of the iron homeostasis

7 system, regulating cellular iron levels. Both serotransferrin and hemopexin appeared

8 in our study to be down-regulated by crude oil exposure, which might in turn lead to

9 an overload of iron (Bradbury, 1997, Anderson \& Frazer, 2005). In cells, like

10 macrophages, only a slight increase in iron (2-3 fold) is found to affect cell signalling,

11 leading to NO production and activation of the nuclear transcription factor NF kappa

$12 \mathrm{~B}$, and cellular function, resulting in a stimulation of the production of reactive

13 oxygen species (ROS) and oxidative stress (Chrichton et al., 2002).

14

15 Our results may also indicate an effect of crude oil exposure on lipid metabolism.

16 Both prepro-apolipoprotein and apolipoproteins B (Apo B) appared to be

17 differentially expressed after 24 days of exposure. Apolipoproteins are important

18 regulators of triglyceride and cholesterol metabolism. Previously, oestrogen has been

19 shown to affect the density distribution of apolipoproteins (Tam et al., 1985).

21 We also found a NTPase and fetuin B to be down-regulated in the groups of 22 individuals exposed to $1.0 \mathrm{mgL}^{-1}$ crude oil and surrogate produced water. This 23 NTPase is found in apoptosis as well as being involved in MHC transcription 24 activation. Fetuin B is a protease inhibitor of many functions, such as regulation of 25 insulin and hepatocyte growth factor receptors, in response to systemic inflammation 
1 and in osteogenesis (Binkert et al.,1999). The apparent down-regulation of these

2 proteins may thus have several adverse effects in the exposed fish.

3

4 When evaluating these differentially expressed proteins as biomarker candidates, it is

5 important to be aware of the limited number of individuals within each group. We are

6 in the first phase of biomarker development with limited amount of samples available

7 for biomarker discovery. Hence, the results from this study may include a number of

8 false positives, although we chose to use a filter of $>2$ fold-change, in addition to $p$ -

9 values $<0.05$ (ANOVA) for selecting candidates for further processing. Further

10 analysis, verification, and validation of these results will determine whether they are

11 suited for use as biomarkers in the future (Rifai et al., 2006).

12

13 As well as trying to identify more of the proteins observed to be differentially

14 expressed in this study, our strategy involves producing antibodies directed towards

15 these biomarker candidates. The candidates will be validated for use as biomarkers

16 using antibodies in ELISA assays. The antibodies may also be used in mechanistic

17 studies to gain more knowledge of the underlying mechanisms of action of oil

18 hydrocarbons and alkyl phenols in fish.

19 


\section{Conclusion}

3 We found the Ludesi software to provide robust image analysis for biomarker

4 candidate discovery. By this approach we observed 137 proteins to be differentially

5 expressed due to exposure, and 29 of these proteins were successfully identified by

6 mass spectrometry. Taken together, our findings suggest alpha enolase, plasminogen,

7 alpha-1-antitrypsin, alpha-2-macroglobulin, alpha-2-antiplasmin, prothrombin,

8 pentraxin, tropomyosin, serotransferrin, hemopexin, fetuin $B$, apolipoprotein $B$, the

9 NTPase and the Pzp proteins as potential biomarker candidates in plasma for the

10 effects of oil and produced water to fish. Changes in protein expression were observed

11 also at low levels of exposure for many of the proteins, which indicates effects on fish

12 at lower levels of exposure than previously reported. However, their use as future

13 biomarkers has to be tested at a much larger scale in future studies. Also many of the

14 responses seen in this study seem to be somewhat linked to each other, indicating that

15 an array of these biomarker candidates used together may give a better indication of

16 adverse effects in the fish induced by oil and/or produced water compared to single

17 biomarkers alone.

18 


\section{Acknowledgements}

2

3 We thank Prof. Peter Roepstorff, Nicolai Bache and Andrea Marie Lorentzen in the

4 Protein Research group at The Southern Danish University, Odense, Denmark, for

5 valuable input, training and access to their MALDI-Tof-Tof instrument, which has

6 been a valuable contribution to our work with cod protein identification by mass

7 spectrometry. LC-MS-MS runs were performed by PROBE, the Proteomic platform at

8 the University of Bergen. We also thank Magnus Artnzen at PROBE for excellent

9 service and valuable input. Pål Olsvik, NIFES, Bergen, Norway, and Frank Nilsen,

10 the Institute of Marine Research, Bergen, Norway, gave us access to more than 50.

11000 cod ESTs in the database, and Anders Lanzen and Pål Puntervoll, the

12 Computational Biology Unit made the database searchable, which has been essential

13 to retrieving these results, and this co-operation is highly appreciated. Our work was

14 financially supported by Total Norway AS and the Norwegian Research Council

15 (grant 1644243/ S40, 159197/I20 and 165233/S40, and The National Functional

16 Genomics Programme - FUGE). 


\section{References}

2

3

4

Aas E, Baussant T, Balk L, Liewenborg B, Andersen OK. 2000. PAH metabolites in bile, cytochrome P4501A and DNA adducts as environmental risk parameters for chronic oil exposure: a laboratory experiment with Atlantic cod. Aquatic Toxicology 51(2):241-258.

Anderson GJ, Frazer DM. 2005. Hepatic iron metabolism. Seminars in Liver Disease 25(4):420-432. 20(1):68-72.

Binkert C, Demetriou M, Sukhu B, Szweras M, Tenenbaum HC, Dennis JW. 1999. Regulation of osteogenesis by fetuin. $\square$ Journal of Biological Chemistry 274:28514-20.

Bottazzi B, Garlanda C, Salvatori G, Jeannin P, Manfredi A, Mantovani A. 2006. Pentraxins as a key component of innate immunity. Current Opinion in Immunology 18(1):10-15.

Bradbury MW. 1997. Transport of iron in the blood-brain-cerebrospinal fluid system. Journal of Neurochemistry 69(2):443-454.

Bradford M. 1976. A rapid and sensitive method for the quantitation of microgram quantities of protein utilizing the principle of protein-dye binding. Analytical

Biochemistry 72:248-254.

Cardinali M, Maradonna F, Olivotto I, Bortoluzzi G, Mosconi G, Polzonetti-Magni AM, et al. 2004. Temporary impairment of reproduction in freshwater teleost exposed to nonylphenol. Reproductive Toxicology 18(4):597-604.

Carls MG, Babcock, M.M., Harris, P.M., Irvine, G.V., Cusick, J.A., Rice,S.D. 2001. Persistence of oiling in mussel beds after the Exxon Valdez oil spill. Marine Environmental Research 51(2):167-190 
1 Crichton RR, Wilmet S, Legssyer R, Ward RJ. 2002. Molecular and cellular

2

3

4 mechanisms of iron homeostasis and toxicity in mammalian cells. Journal of Inorganic Biochemistry 91(1): 9-18.

Evanson M, Van Der Kraak GJ. 2001. Stimulatory effects of selected PAHs on testosterone production in goldfish and rainbow trout and possible mechanisms of action. Comparative Biochemistry and Physiology part C Toxicology and Pharmacology 130(2):249-258.

Gobom J, Nordhoff E, Mirgorodskaya E, Ekman R, Roepstorff P. 1999. Sample Purification and Preparation Technique Based on Nano-scale Reverse Phase Columns for the Sensitive Analysis of Complex Peptide Mixtures by Matrixassisted Laser Desorption/Ionization Mass Spectrometry. Journal of Mass Spectrometry 34:105-116.

Görg A, Obermaier, C., Boguth, G., Harder, A., Scheibe, B., Wildgruber, R., Wiess, W. 2000. The current state of two-dimensional electrophoresis with immobilized pH-gradients. Electrophoresis 21:1037-1053.

Görg A, Postel, W., Günther,S. 1988. Two-dimensional electrophoresis. Electrophoresis 9:531-546.

Hayashido Y, Hamana T, Ishida Y, Shintani T, Koizumi K, Okamoto T. 2007. Induction of alpha2-antiplasmin inhibits E-cadherin processing mediated by the plasminogen activator/plasmin system, leading to suppression of progression of oral squamous cell carcinoma via upregulation of cell-cell adhesion. Oncology Reports 17(2):417-423.

Heukeshoven J, Dernick R. 1988. Improved silver staining procedure for fast staining in PhastSystem Development Unit. I. Staining of sodium dodecyl sulfate gels. Electrophoresis 9(1):28-32. 
1 Jewett SC, Dean TA, Woodin BR, Hoberg MK, Stegeman JJ. 2002. Exposure to

2 hydrocarbons 10 years after the Exxon Valdez oil spill: evidence from

3 cytochrome P4501A expression and biliary FACs in nearshore demersal

4 fishes. Marine Environmental Research 54(1):21-48.

5 Laemmli UK. 1970. Cleavage of structural proteins during the assembly of the head of bacteriophage T4. Nature 227(5259):680-685.

7 Lee RF, Andersson, J.W. 2005. Significance of cytochrome P450 system responses and levels of bile fluorescent aromatic compounds in marine wildlife following oil spills. Marine Pollution Bulletin 50(705-723).

Liu Y. 2007. Involvement of plasminogen activatorinhibitor type 1 in spermatogenesis, sperm capacitation, and fertilization. Seminars in Thrombosis and Hemostasis 33(1):29-40.

Machovich R, Horvath I. 1981. Thrombin and haemostasis: regulation of the biological functions of thrombin. (Facts and perspectives). Haematologia

16 Marekov LN, Steinert PM. 2003. Charge derivatization by 4-sulfophenyl isothiocyanate enhances peptide sequencing by post-source decay matrixassisted laser desorption/ionization time-of-flight mass spectrometry. Journal

23 Molloy MP, Brzezinski EE, Hang J, McDowell MT, VanBogelen RA. 2003. proteomics. Proteomics 3(10):1912-1919. 
1 Myhre LP, Bausant, T., Sundt, R., Sanni, S., Vabø, R., Skjoldal, H.R., Klungsøyr, J.

2

3

4 2005. Risk Assessment of reproductive effects of alkyl phenols in produced water on fish stocks in the North Sea AM-2004/018.

Neff JM. 2002. Bioaccumulation in marine organisms. Effect of contaminants from oil well produced water. Elsevier Science Publishers, Amsterdam.

Neuhoff V, Arold N, Taube D, Ehrhardt W. 1988. Improved staining of proteins in polyacrylamide gels including isoelectric focusing gels with clear background at nanogram sensitivity using Coomassie Brilliant Blue G-250 and R-250. Electrophoresis 9(6):255-262.

Nicholas JM. 1999. Vitellogenesis in fish and the effects of polycyclic aromatic hydrocarbon contaminants. Aquatic Toxicology 45(2-3):77-90.

O`Farrell PH. 1975. High resolution two-dimensional electrophoresis of proteins. Journal of Biological Chemistry 250(10):4007-4021.

OLF 2005. Environmental Report 2004. Stavanger, Norway: Oljeindustriens landsforening (OLF).

OSPAR 2006. OSPAR Recommendation 2006/4 Amending OSPAR Recommendation 2001/1 for the management of Produced water from Offshore Installations. OSPAR 06/23/1-E, Annex 15.

Perkins DN, Pappin, D.J., Creasy, D.M., Cottrell, J.S. 1999. Probability-based protein identification by searching sequence databases using mass spectrometry data Electrophoresis 20:3551-3567.

Rappsilber J, Ishihama Y, Mann M. 2003. Stop and go extraction tips for matrixassisted laser desorption/ionization, nanoelectrospray, and LC/MS sample pretreatment in proteomics. Analytical Chemistry 75(3):663-670. 
1 Rifai N, Gerszten RE. 2006. Biomarker discovery and validation. Clinical Chemistry

2

3

4 52(9):1635-1637.

Schwaiger J, Mallow U, Ferling H, Knoerr S, Braunbeck T, Kalbfus W, et al. 2002. How estrogenic is nonylphenol? A transgenerational study using rainbow trout (Oncorhynchus mykiss) as a test organism. Aquatic Toxicology 59(3-4):177189.

Schwarzenberg SJ, Sharp HL, Berry SA, Manthei RD, Seelig S. 1987. Hormonal regulation of serum alpha 1-antitrypsin and hepatic alpha 1-antitrypsin mRNA in rats. Biochemical and Biophysical Research Communications 147(3):936941.

Shevchenko A, Sunyaev, S., Loboda, A., Shevchenko, A., Bork, P., Ens, W., and Standing, K.G. 2001. Charting the proteomes of organisms with unsequenced genomes by Maldi-Quadrupole Time-of-Flight Mass Spectrometry and BLAST homology SEARCHING. Analytical Chemistry 73:1917-1926.

Shevchenko A, Wilm M, Vorm O, Mann M. 1996. Mass spectrometric sequencing of proteins silyer-stained polyacrylamide gels. Analytical Chemistry 68(5):850858.

Skadsheim A 2005. Cod stocks exposed to crude oils: Uptake, metabolism and biomarker effects. Report AM-2004/005. IRIS-Akvamiljø, Norway (ISBN 828192-007-6).

Solé M, Porte, C., Biosca, X., Mitchelmore, C.L., Chipman, J.K., Livingstone, D.R., Albaigés, J. 1996. Effects of the "Aegean Sea" oil spill on biotransformation enzymes, oxidative stress and DNA adducts in digestive gland of the Mussel (Mytilus edulus L.). Comparative Biochemistry and Physiology part C Vol 113 $C(2): 257-265$. 
1 Steen H, Mann M. 2004. The ABC's (and XYZ's) of peptide sequencing. Nature

2 Reviews in Molecular Cell Biology 5(9):699-711.

3 Tam SP, Archer TK, Deeley RG. 1985. Effects of estrogen on apolipoprotein

4

7
secretion by the human hepatocarcinoma cell line, HepG2. Journal of Biological Chemistry 260(3):1670-1675.

Terrier B, Degand N, Guilpain P, Servettaz A, Guillevin L, Mouthon L. 2007. Alphaenolase: A target of antibodies in infectious and autoimmune diseases. Autoimmunity Reviews 6(3):176-182.

Thomas L, Moore NR, Miller S, Booth NA. 2007. The C-terminus of alpha2antiplasmin interacts with endothelial cells. British Journal of Haematology 136(3):472-479.

Tolosano E, Altruda F. 2002. Hemopexin: structure, function, and regulation. DNA and Cell Biology 21(4):297-306.

Yamamoto K, Sinohara H. 1984. Regulation by sex hormones of serum levels of contrapsin and alpha 1-antiprotease in the mouse. Biochimica et Biophysica Acta 798(2):231-234.

18

(1)


1 Table 1: Relative protein expression levels in cod plasma following 3 days of exposure to crude oil

\begin{tabular}{|c|c|c|c|c|c|c|}
\hline \multirow{2}{*}{$\underset{b}{\text { Spot \# }}$} & \multicolumn{5}{|c|}{ Relative protein expression levels } & \multirow[t]{2}{*}{ Protein identity } \\
\hline & $\begin{array}{l}\text { Control } \\
\left(82,83^{c}\right) \\
\end{array}$ & $\begin{array}{l}0.06 \mathrm{mgL}^{-1} \\
\mathrm{CO}^{\mathrm{d}} \\
(84,85,86)\end{array}$ & $\begin{array}{c}0.25 \mathrm{mgL}^{-1} \\
\mathrm{CO} \\
(87,88,89) \\
\end{array}$ & $\begin{array}{c}1.0 \mathrm{mgL}^{-1} \\
\mathrm{CO} \\
(90)\end{array}$ & $\begin{array}{c}1.0 \mathrm{mgL}^{-1} \\
\mathrm{sPW}^{\mathrm{e}} \\
(91)\end{array}$ & \\
\hline 6986 & 1 & 5.2 & 5.9 & 7.5 & 4.1 & \\
\hline 7013 & 1 & 0.5 & 0 & 0 & 2.3 & Fibrinogen \\
\hline 7029 & 1 & 1.2 & 1.4 & 1.9 & 0 & \\
\hline 7057 & 1 & 0.7 & 4.2 & 9.0 & 6.3 & \\
\hline 7087 & 0 & 1 & 0 & 3.0 & 0 & \\
\hline 7105 & 1 & 5.4 & 7.6 & 8.1 & 0 & \\
\hline 7188 & 1 & 0.9 & 0.7 & 3.3 & 6.6 & \\
\hline 7264 & 0 & 1 & 2.4 & 5.8 & 3.2 & 2 \\
\hline 7454 & 1 & 0.1 & 0.4 & 0.7 & 0.4 & \\
\hline 7526 & 1 & 0.8 & 1.2 & 6.2 & 3.1 & 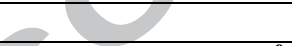 \\
\hline 7550 & 1 & 0 & 0.1 & 0 & 1.1 & Hypothetical (A2A $\left.{ }^{f}\right)$ \\
\hline 7561 & 1 & 0.5 & 0.1 & 6.4 & 0 & \\
\hline 7602 & 1 & 2.4 & 2.1 & 9.8 & 2.9 & \\
\hline 7611 & 1 & 2.8 & 2.4 & 0.7 & 8.7 & \\
\hline 7632 & 1 & 0.2 & 1.6 & 0.5 & 0 & \\
\hline 7644 & 1 & 0.9 & 4.7 & 9.7 & 7.8 & \\
\hline 7647 & 1 & 0.4 & 1.4 & 2.1 & 0.8 & \\
\hline 7667 & 0 & 1 & 2.2 & 8.0 & 0 & \\
\hline 7709 & 1 & 0 & 2.3 & 0 & 7.7 & Fibrinogen \\
\hline 7715 & 1 & 0.1 & 0 & 0.5 & 1.8 & \\
\hline 7739 & 0 & 1 & 10.9 & 0 & 7.9 & \\
\hline 7814 & 1 & 0.1 & 0.3 & 0.1 & 0.1 & \\
\hline 7842 & 1 & 2.7 & 1.7 & 1.3 & 4.1 & \\
\hline 7848 & 1 & 1.9 & 9.3 & 6.8 & 19.1 & \\
\hline 8005 & 0 & 0 & 1 & 6.1 & 0 & \\
\hline 8039 & 1 & 0.8 & 0 & 4.1 & 1.9 & \\
\hline 8115 & 1 & 0 & 1.3 & 1.8 & 4.9 & \\
\hline 8153 & 1 & 0.1 & 0 & 0 & 2.2 & \\
\hline 8411 & 1 & 0 & 0 & 0 & 0 & \\
\hline 8418 & 0 & 0 & 1 & 4.1 & 0 & \\
\hline 8593 & 0 & 1 & 9.2 & 37.9 & 0 & \\
\hline 8756 & 1 & 5.1 & 3.3 & 37.6 & 0 & \\
\hline 8769 & 1 & 0 & 0 & $\mathbf{1 0 . 5}$ & 0 & \\
\hline 8786 & 1 & 0 & 0 & 22.0 & 0 & \\
\hline 9439 & 1 & 0 & 1.3 & 0 & 0 & Fibrinogen \\
\hline
\end{tabular}

3 a Summary of relative protein changes in cod plasma following exposure found by image analysis

4 (Ludesi Interpreter) of 2D gels. Bold font type indicates a significant up-regulation (ANOVA: $p<0.05$,

5 fold change $\geq 2$ in protein expression) of a protein as compared to control (or lowest detectable level in any group, if control is below detectable level). Italics is used for significant down-regulation

(ANOVA: $\mathrm{p}<0.05$, fold change $<0.5$ in protein expression) of a protein as compared to control. $\mathrm{n}=1-3$

8 in groups (identified by sample no. in parentheses).

$9{ }^{b}$ Spot no. are shown with 2D localization in Fig. 1.

10 sample of female individual

$11{ }^{\mathrm{d}} \mathrm{CO}$ - crude oil treated juveniles.

12 e $\mathrm{sPW}$ - surrogate produced water $\left(1.0 \mathrm{mgL}^{-1}\right.$ crude oil plus alkylphenol and hydrocarbon spike)-treated 13 juveniles

$14 \quad{ }^{\mathrm{f}} \mathrm{A} 2 \mathrm{~A}$ - Alpha-2-antiplasmin 
1 Table 2: Relative protein expression levels in cod plasma following 24 days of exposure to crude

2

Table 2: Relative protein expression levels in
oil and surrogate produced water ${ }^{\mathrm{a}}$

\begin{tabular}{|c|c|c|c|c|c|c|}
\hline Spot $\#^{b}$ & $\begin{array}{c}\text { Relative } p \\
\text { Control } \\
(62,63)\end{array}$ & $\begin{array}{c}\text { tein expressi } \\
0.06 \mathrm{mgL}^{-1} \\
\mathrm{CO}^{\mathrm{c}} \\
(68)\end{array}$ & $\begin{array}{c}\text { n levels } \\
0.25 \mathrm{mgL}^{-1} \\
\text { CO } \\
(69,70)\end{array}$ & $\begin{array}{c}1.0 \mathrm{mgL}^{-1} \\
\mathrm{CO} \\
(74,75,76)\end{array}$ & $\begin{array}{c}1.0 \mathrm{mgL}^{-1} \\
\mathrm{SPW}^{\mathrm{d}} \\
(\mathbf{7 9 , 8 1})\end{array}$ & Protein identity \\
\hline 6965 & 1 & 0 & 0 & 0 & 0 & \\
\hline 6971 & 1 & 0.4 & 0.7 & 0.3 & 0.6 & \\
\hline 6983 & 1 & 1.3 & 0.2 & 0.9 & 0.7 & \\
\hline 6984 & 1 & 0 & 0 & 0 & 0 & \\
\hline 6989 & 1 & 0 & 0 & 0 & 0 & \\
\hline 7001 & 1 & 0.3 & 0.5 & 0.2 & 0.6 & \\
\hline 7011 & 1 & 0 & 0 & 0 & 0 & Alpha enolase \\
\hline 7018 & 1 & 0.7 & 0 & 0 & 1.3 & \\
\hline 7020 & 1 & 0.5 & 1.2 & 0.1 & 0.3 & $A 2 M^{e}$ \\
\hline 7021 & 1 & 0.6 & 1.1 & 0.3 & 0.4 & \\
\hline 7027 & 1 & 1.1 & 1.1 & 1.4 & 0 & PTX \\
\hline 7032 & 1 & 2.9 & 0.4 & 2.5 & 2.2 & Fibrinogen \\
\hline 7043 & 1 & 0.6 & 0.6 & 0.2 & 0.3 & Tropomyosin \\
\hline 7051 & 1 & 1.9 & 0.3 & 1.2 & 1.9 & \\
\hline 7053 & 1 & 0.6 & 0.8 & 0.3 & 0.4 & \\
\hline 7055 & 1 & 1.7 & 0 & 2.1 & 1.9 & \\
\hline 7057 & 1 & 0 & 1.5 & 0.4 & 0 & \\
\hline 7069 & 1 & 1.1 & 2.0 & 1.6 & 0.5 & \\
\hline 7071 & 1 & 0 & 0 & 0 & 0.2 & \\
\hline 7072 & 1 & 3.2 & 0 & 2.0 & 2.4 & \\
\hline 7073 & 1 & 0 & 0 & 0 & 0.3 & \\
\hline 7077 & 1 & 1.9 & 1.6 & 1.0 & 0.4 & \\
\hline 7081 & 1 & 0.7 & 1.1 & 0.4 & 0.1 & \\
\hline 7082 & 1 & 0.6 & 1.4 & 0.2 & 0.2 & \\
\hline 7084 & 1 & 0 & 0 & 0 & 0 & \\
\hline 7098 & 1 & 1.3 & 0.6 & 1.7 & 2.1 & Fetuin B \\
\hline 7125 & 1 & 1.7 & 0 & 0 & 1.1 & \\
\hline 7140 & 1 & 1.6 & 2.7 & 1.3 & 1.2 & \\
\hline 7143 & & 1.2 & 0.7 & 1.2 & 0.2 & \\
\hline 7144 & 1 & 6.8 & 1.2 & 2.0 & 0 & \\
\hline 7160 & 1 & 0.7 & 1.0 & 0.4 & 0.3 & \\
\hline 7178 & 1 & 0 & 2.4 & 0 & 0.4 & Apolipoprotein B \\
\hline 7180 & 1 & 0 & 0 & 0 & 0 & \\
\hline 7186 & 1 & 0 & 1.2 & 0 & 0 & \\
\hline 7192 & 1 & 0.3 & 0.9 & 0 & 0.1 & Serotransferrin \\
\hline 7197 & 1 & 0.8 & 0 & 0.1 & 0 & A2M \\
\hline 7215 & 1 & 1.3 & 2.5 & 0.5 & 0.9 & \\
\hline 7228 & 1 & 2.7 & 5.1 & 1.7 & 1.7 & \\
\hline 7240 & 1 & 0 & 0.9 & 0.4 & 0.5 & \\
\hline 7241 & 1 & 2.0 & 0.8 & 2.9 & 2.1 & \\
\hline 7259 & 1 & 5.8 & 0 & 4.4 & 0.5 & \\
\hline 7285 & 1 & 0 & 0.4 & 0 & 1.2 & $\begin{array}{l}\text { Prothrombin } \\
\text { Unnamed }\end{array}$ \\
\hline 7288 & 1 & 1.6 & 0.2 & 0.2 & 0 & \\
\hline 7294 & 1 & 0.2 & 1.6 & 0.2 & 0.6 & \\
\hline
\end{tabular}




\begin{tabular}{|c|c|c|c|c|c|c|}
\hline 7300 & 1 & 1.1 & 0.7 & 1.8 & 0.3 & \\
\hline 7315 & 1 & 2.0 & 10.0 & 3.0 & 0.9 & \\
\hline 7329 & 1 & 0 & 0.3 & 0 & 0 & $\begin{array}{l}\text { Prothrombin } \\
\text { Fetuin B }\end{array}$ \\
\hline 7336 & 1 & 2.8 & 3.4 & 0.5 & 1.5 & \\
\hline 7341 & 1 & 3.5 & 1.4 & 2.6 & 1.9 & \\
\hline 7342 & 1 & 0 & 0.2 & 0 & 0.4 & \\
\hline 7345 & 1 & 0.5 & 0 & 0.5 & 0 & Fetuin B \\
\hline 7409 & 1 & 0 & 0.1 & 0.1 & 0.5 & HX \\
\hline 7429 & 1 & 14.5 & 4.9 & 0 & 4.0 & \\
\hline 7433 & 1 & 0.1 & 1.0 & 0.1 & 0.3 & \\
\hline 7437 & 1 & 0.1 & 0 & 0 & 0 & \\
\hline 7457 & 1 & 0 & 1.1 & 19.3 & 0 & \\
\hline 7477 & 1 & 2.3 & 9.5 & 0 & 0.3 & $\mathrm{~A} 2 \mathrm{M}$ \\
\hline 7506 & 1 & 8.3 & 0 & 8.3 & 7.6 & \\
\hline 7525 & 1 & 0 & 0.7 & 4.3 & 5.4 & ( ) \\
\hline 7581 & 1 & 1.7 & 0.6 & 2.2 & 2.4 & A2A \\
\hline 7584 & 1 & 1.5 & 0 & 2.1 & 2.3 & A2A \\
\hline 7587 & 1 & 1.5 & 1.0 & 2.2 & 2.8 & \\
\hline 7597 & 1 & 1.0 & 0 & 1.6 & 2.1 & $\mathbf{A 2 A}$ \\
\hline 7633 & 1 & 1.2 & 2.0 & 0 & 0 & \\
\hline 7665 & 1 & 0.5 & 0.7 & 0.3 & 0.3 & $\begin{array}{l}\text { Hypothetical } \\
\text { APO B } \\
\text { Uncharacterized }\end{array}$ \\
\hline 7678 & 1 & 0.9 & 0.5 & 0.8 & 0 & \\
\hline 7705 & 1 & 0.9 & 2.2 & 0.5 & 0.8 & \\
\hline 7715 & 1 & 4.1 & 3.9 & 2.0 & 2.3 & \\
\hline 7725 & 1 & 11.9 & 0 & 7.0 & 1.0 & \\
\hline 7726 & 1 & 4.2 & 3.7 & 2.2 & 2.3 & \\
\hline 7746 & 1 & 0 & 0 & 0 & 0 & \\
\hline 7748 & 1 & 2.1 & 0.6 & 0 & 0 & \\
\hline 7806 & 1 & 1.4 & 1.1 & 0.9 & 0 & \\
\hline 7807 & 1 & 0 & 0.2 & 0.3 & 0.8 & \\
\hline 7810 & 1 & 0.7 & 1.4 & 0.5 & 0.3 & NTPase \\
\hline 7811 & & 1.7 & 3.4 & 0 & 0 & A1AT \\
\hline 7814 & 1 & 0 & 1.4 & 1.5 & 0 & \\
\hline 7826 & 1 & 0.6 & 0.5 & 0.3 & 0.6 & PZP \\
\hline 7843 & 1 & 0.6 & 0.5 & 1.7 & 2.1 & \\
\hline 7854 & 1 & 0 & 0 & 0.2 & 0.4 & \\
\hline 7864 & 1 & 0.6 & 1.1 & 0 & 0.5 & \\
\hline 7878 & 1 & 0 & 0.3 & 1.4 & 8.5 & \\
\hline 7922 & 1 & 13.5 & 0 & 16.1 & 4.2 & \\
\hline 8007 & 1 & 1.9 & 3.4 & 0.3 & 0.5 & \\
\hline 8033 & 1 & 7.0 & 3.7 & 1.6 & 0 & \\
\hline 8039 & 1 & 1.9 & 7.6 & 1.5 & 0.9 & \\
\hline 8102 & 1 & 0 & 0 & 3.3 & 10.1 & \\
\hline 8162 & 1 & 6.6 & 6.0 & 1.2 & 0 & \\
\hline 8189 & 0 & 0 & 0 & 1 & 0 & \\
\hline 8381 & 0 & 0 & 1 & 0 & 0 & \\
\hline 8397 & 0 & 0 & 1 & 66.8 & 0 & \\
\hline 8409 & 0 & 0 & 0 & 0.9 & 1 & \\
\hline
\end{tabular}




\begin{tabular}{llllll}
$\mathbf{8 4 4 8}$ & 0 & 0 & 0 & 0 & $\mathbf{1}$ \\
$\mathbf{8 5 8 0}$ & 0 & 0 & $\mathbf{1}$ & $\mathbf{2 . 0}$ & $\mathbf{2 . 2}$ \\
$\mathbf{8 5 8 1}$ & 0 & 0 & $\mathbf{1}$ & $\mathbf{1 . 0}$ & 0 \\
$\mathbf{8 6 3 6}$ & 0 & 0 & 0 & $\mathbf{0 . 6}$ & $\mathbf{1}$ \\
$\mathbf{8 8 4 1}$ & 0 & 0 & 0 & $\mathbf{2 . 1}$ & $\mathbf{1}$ \\
$\mathbf{8 8 6 4}$ & 0 & $\mathbf{1}$ & 0 & $\mathbf{0 . 1}$ & $\mathbf{1 . 1}$ \\
$\mathbf{8 9 8 5}$ & 0 & 0 & $\mathbf{1}$ & 0 & 0 \\
$\mathbf{9 1 2 8}$ & 0 & 0 & 0 & 0 & $\mathbf{1}$ \\
$\mathbf{9 2 4 4}$ & 0 & 0 & 0 & 0 & $\mathbf{1}$ \\
$\mathbf{9 2 5 7}$ & 0 & 0 & 0 & 0 & $\mathbf{1}$ \\
\hline
\end{tabular}

$1 \quad{ }^{\mathrm{a}}$ Summary of relative protein changes in cod plasma following exposure found by image analysis

2 (Ludesi Interpreter) of 2D gels. Bold font type indicates a significant up-regulation (ANOVA: $\mathrm{p}<0.05$, fold change $\geq 2$ in protein expression) of a protein as compared to control (or lowest detectable level in any group, if control is below detectable level). Italics is used for significant down-regulation (ANOVA: $\mathrm{p}<0.05$, relative fold change $<0.5$ ) of a protein as compared to control. $\mathrm{n}=1-3$ in groups (identified by sample no. in parentheses).

${ }^{\mathrm{b}}$ Spot no. are shown with 2D localization in Fig. 1.

${ }^{\mathrm{c}} \mathrm{CO}$ - crude oil treated juveniles.

${ }^{\mathrm{d}} \mathrm{SPW}$ - surrogate produced water $\left(1.0 \mathrm{mgL}^{-1}\right.$ crude oil plus alkylphenol and hydrocarbon spike)-treated juveniles

11 'Protein abbreviations: A2A; Alpha-2-antiplasmin, HX; Hemopexin, PTX; Pentraxin, A2M: alpha-2-

12 macroglobulin, APO; apolipoprotein, A1AT; Alpha-1-antitrypsin, PZP; Pregnancy zone protein. 
Table 3: Identification of differentially expressed proteins in cod plasma after continuous exposure to crude North Sea oil and surrogate produced water

\begin{tabular}{|c|c|c|c|c|c|c|c|c|}
\hline Spot \# & Acc. no & Protein identity & Score $^{\mathrm{a}}$ & $\begin{array}{l}\text { Queries } \\
\text { matched }^{b}\end{array}$ & $\begin{array}{c}\text { Seq. cov. } \\
\%\end{array}$ & $\begin{array}{l}\text { Observed } \\
\mathrm{pI} / \mathrm{Mr}\end{array}$ & $\begin{array}{l}\text { Theoretical } \\
\mathrm{pI} / \mathrm{Mr}\end{array}$ & $\begin{array}{l}\text { Putative conserved } \\
\text { domains }\end{array}$ \\
\hline $7^{7011^{2}}$ & AAH59511.16 ${ }^{\text {ns }}$ & Enolase 1, (alpha) [Danio rerio] $^{\text {ns }}$ & $72 / 29$ & $2 / 312$ & 9 & $5.9 / 50$ & $6.19 / 47,4$ & Enolase \\
\hline $7_{013}{ }^{2}$ & NP_998219 & Fibrinogen gamma polypeptide [Danio rerio] & 93 & 12 & 39 & $5.0 / 43,5$ & $5.07 / 48,8$ & Fibrinogen \\
\hline $7020^{2}$ & BAA85038 & Alpha-2-macroglobulin-1 [Cyprinus carpio] & 107 & 5 & 17 & $5.3 / 94$ & $5.40 / 160,8$ & $\mathrm{~A} 2 \mathrm{M}$ \\
\hline $7027^{1}$ & ВАВ69039.1 & Pentraxin [Cyprinus carpio] & 108 & 2 & 7 & $4.6 / 25$ & $5.07 / 25,4$ & PTX \\
\hline $7032^{2}$ & CAF96585 & $\begin{array}{l}\text { Unnamed protein product ( fibrinogen) } \\
\text { [Tetraodon nigroviridis] }\end{array}$ & 67 & 6 & 18 & $5.0 / 40$ & $4.96 / 47,3$ & Fibrinogen \\
\hline $\mathbf{7 0 4 3}^{2}$ & CAF98296 $^{\mathrm{ns}}$ & 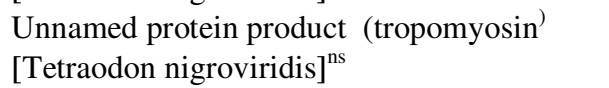 & $52 / 29$ & 2 & 14 & $6.1 / 145$ & $5.01 / 35,2$ & Tropomyosin \\
\hline $7098^{2}$ & CAF98106 & $\begin{array}{l}\text { Hypothetical protein LOC563663 (fetuin B) } \\
\text { [Danio rerio] }\end{array}$ & 137 & 9 & 16 & $4.4 / 100$ & $5.05 / 52,9$ & Fetuin B \\
\hline $7178^{\mathrm{ns}, 2}$ & CAA57449.1 ${ }^{\mathrm{ns}}$ & Apolipoprotein B [Salmo salar $]^{\mathrm{ns}}$ & 58 & 2 & 5 & $4.6 / 46$ & $5.24 / 115,9$ & APO B \\
\hline $7192^{2}$ & Q92079 & Serotransferrin [Gadus norhua] & 852 & 8 & 62 & $6.5 / 75$ & $6.12 / 67.9$ & Transferrins \\
\hline $7197^{2}$ & BAA92285 & Orla C3-1 [Oryzias latipes] & 59 & 5 & 10 & $5.3 / 84$ & $5.9 / 184,5$ & $\mathrm{~A} 2 \mathrm{M}$ \\
\hline $7285^{2}$ & CAD59688 & Prothrombin [Oncorhynchus mykiss] & $463 / 29$ & $12 / 478$ & 15 & $4.9 / 90$ & $6.32 / 70,5$ & Prothrombin \\
\hline $7329^{2}$ & CAD59688 & Prothrombin [Oncorhynchus mykiss] & $660 / 29$ & $21 / 426$ & 29 & $4.9 / 90$ & $6.32 / 70,5$ & Prothrombin \\
\hline & CAF98106 & $\begin{array}{l}\text { Unnamed protein product (fetuin B) } \\
\text { [Tetraodon nigroviridis] }\end{array}$ & $298 / 29$ & $9 / 426$ & 13 & $4.9 / 90$ & $5.99 / 56.1$ & Fetuin B \\
\hline $7345^{2}$ & CAF98106 & $\begin{array}{l}\text { Unnamed protein product [Tetraodon } \\
\text { nigroviridis] }\end{array}$ & $225 / 29$ & $6 / 594$ & 11 & $4.5 / 90$ & $5.99 / 56.1$ & Fetuin B \\
\hline $7409^{2}$ & XP_691686 & Predicted: Hemopexin [Danio rerio] & $302 / 28$ & $9 / 428$ & 26 & $4.4 / 75$ & $6.02 / 45,4$ & Hemopexin, HX \\
\hline $7550^{2}$ & NP_001073479.1 & $\begin{array}{l}\text { Hypothetical protein LOC563663 (A2M) } \\
\text { [Danio rerio] }\end{array}$ & & 11 & 21 & $4.4 / 80$ & $5.05 / 52.9$ & $\mathrm{~A} 2 \mathrm{~A}$ \\
\hline $7581^{2}$ & NP_001073479.1 & $\begin{array}{l}\text { Hypothetical protein LOC563663 (A2M) } \\
\text { [Danio rerio] }\end{array}$ & 326 & 11 & 21 & $4.5 / 95$ & $5.05 / 52.9$ & $\mathrm{~A} 2 \mathrm{~A}$ \\
\hline $7584^{2}$ & NP_001073479.1 & $\begin{array}{l}\text { Hypothetical protein LOC563663 (A2M) } \\
\text { [Danio rerio] }\end{array}$ & 326 & 11 & 21 & $4.4 / 95$ & $5.05 / 52.9$ & $\mathrm{~A} 2 \mathrm{~A}$ \\
\hline $7597^{2}$ & NP_001073479.1 & $\begin{array}{l}\text { Hypothetical protein LOC563663 [Danio } \\
\text { rerio] }\end{array}$ & 326 & 11 & 21 & $4.3 / 95$ & $5.05 / 52.9$ & $\mathrm{~A} 2 \mathrm{~A}$ \\
\hline \multirow[t]{2}{*}{$7665^{2}$} & NP_001025233.1 & $\begin{array}{l}\text { Hypothetical protein LOC321166 [Danio } \\
\text { rerio] }\end{array}$ & $645 / 28$ & $27 /$ & 84 & $4.6 / 40$ & $5.11 / 412,6$ & $\begin{array}{l}\text { Lipoprotein, function } \\
\text { unknown }\end{array}$ \\
\hline & CAA57449.1 & Apolipoprotein B [Salmo salar] & $675 / 28$ & $17 /$ & 38 & $4.6 / 40$ & $5.24 / 115,9$ & APO B \\
\hline
\end{tabular}




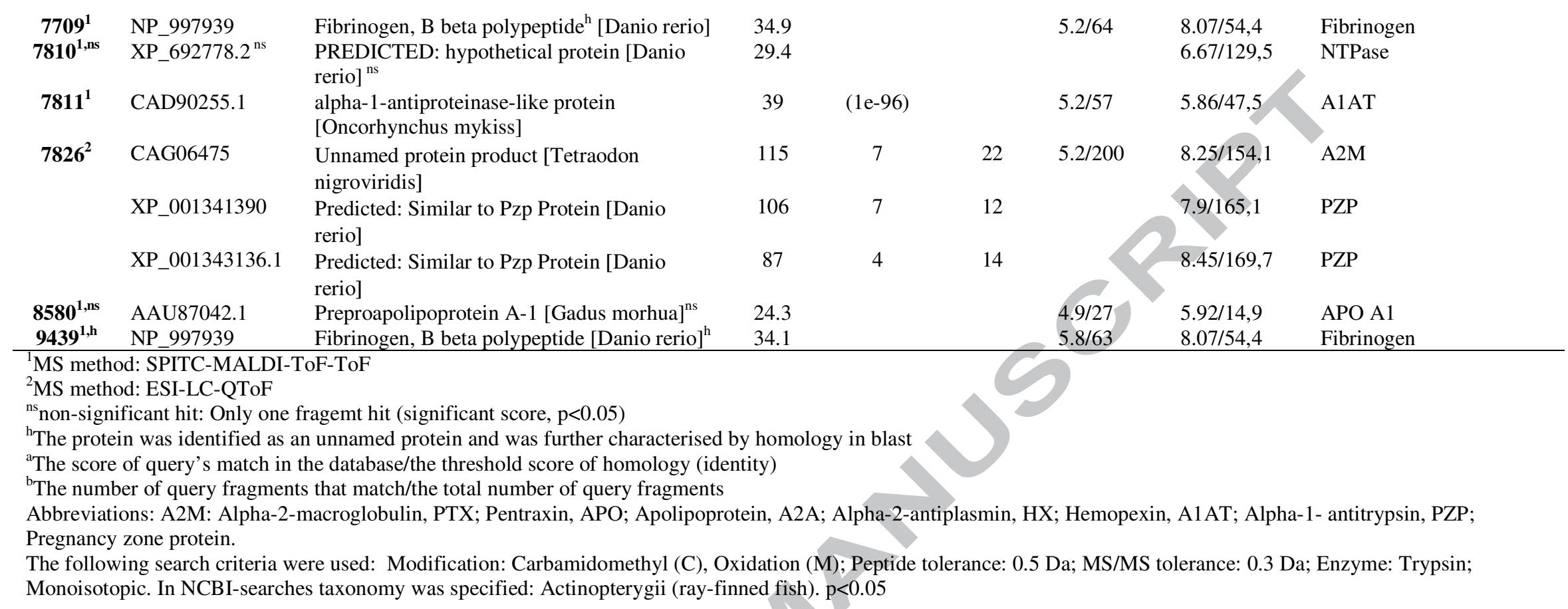


Figure legend

Figure 1: Localisation of differentially expressed cod plasma proteins on the 2DE gel.

A 2DE gel of an individual sample of juvenile cod plasma exposed to $1.0 \mathrm{mgL}^{-1}$ crude North Sea oil. $20 \mu \mathrm{g}$ protein were loaded to a $7 \mathrm{~cm}$ pH4-7 IPG strip and separated in the second dimension on a 9\% SDS PAGE gel. All the 137 protein spots with significant changes (ANOVA: $p<0.05$, fold change $\geq 2$ ) from all the different treatment groups $\left(0.06 \mathrm{mgL}^{-1}, 0.25 \mathrm{mgL}^{-1}\right.$ and $1.0 \mathrm{mgL}^{-1}$ crude oil, and crude oil spiked with PAH and alkyl phenols) are shown. 

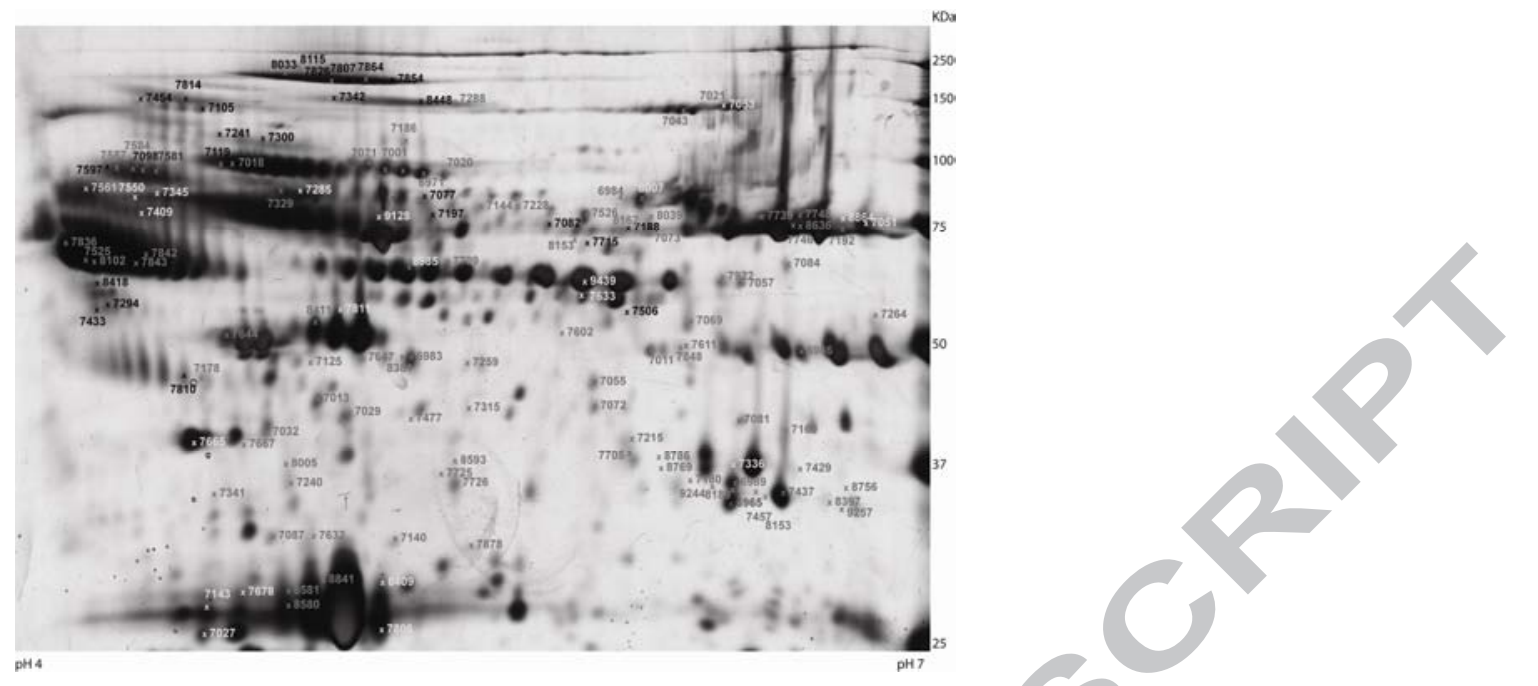